\title{
Biyofilik Tasarımın Diyarbakır Geleneksel Konutlarında Araştırılması
}

\author{
Fatma Demet AYKAL ${ }^{1 *}$ (D) , Meltem ERBAŞ ÖZít ${ }^{2}$ (D) \\ ORCID 1: 0000-0003-2424-0407 \\ ORCID 2: 0000-0003-2077-8728 \\ 1,2 Dicle Üniversitesi, Mimarlık Fakültesi, Mimarlık Bölümü, 21280, Diyarbakır, Türkiye. \\ *e-mail: demetaykal@gmail.com
}

Öz

Günümüzde yapay çevrenin yarattığı sonuçlar, doğanın tahrip edilmesini, doğallığın bozulmasını ve insanların da doğadan kopmasını beraberinde getirmiştir. Insanlar var olduklarından bu yana, doğayla iç içe yaşamını sürdürürken, günümüzde yapma çevreye bağımlı yaşamaya başlamışlardır. Bu süreç insanlarda olumsuz etkiler doğurmuş hem fiziksel hem de ruhsal sağlık sorunlarına yol açmıştır. Insanların yapay çevrede yaşadığı bu sıkıntıların azaltılması ve insan-doğa etkileşiminin yeniden sürdürülebilmesi için mimaride farklı stratejiler geliştirilmiștir. Bunlardan biri de mimaride biyofilik tasarım olmuștur. Biyofilik tasarımda yapay çevre ile doğa bağlantısı tekrar oluşturularak, mekân konforu ve insanların ruhsal- fiziksel sağığının yükseltilmesi amaç edinilmiştir. Çalışmada biyofili ve biyofilik tasarım kavramlarının temel boyutları ile tanımlanarak, tarihi süreç içerisinde yaklaşımın kullanıldığı alanlar ve tasarım stratejilerinin uygulanması açısından deneyimler ve özellikler açıklanmıştır. Bu kapsamda Diyarbakır geleneksel evleri üzerinden gözlem metoduyla biyofilik tasarım incelenmiştir. Seçilen evlerde biyofilik niteliklerin varlığı tespit edilerek ilgili çizim ve fotoğraflarla desteklenmiş ve böylece biyofilik tasarım unsurlarının varlığı/yokluğu ve nelerin kullanıldığı belirlenmeye çalışılmıştır.

Anahtar Kelimeler: Biyofili, biyofilik tasarım, Diyarbakır geleneksel evler

\section{The Research of Biophilic Design in the Traditional Houses of Diyarbakır}

\begin{abstract}
Today, the results created by the artificial environment have brought about the destruction of nature, the deterioration of naturalness and the separation of people from nature. While people have been living in nature since their existence, they have started to depend on the built environment today. This process had negative effects on humans; it has caused both physical and mental health problems. Different strategies have been developed in architecture in order to reduce these problems that people experience in the artificial environment and to maintain human-nature interaction again. One of them has been biophilic design in architecture. In this study, biophilic and biophilic design concepts are defined, the areas where the approach is used in the historical process and the experiences and features in terms of the implementation of design strategies are explained. In this context, biophilic design was examined by observation method through Diyarbakır traditional houses.
\end{abstract}

Keywords: Biophilia, biophilic design, Diyarbakır traditional houses

Atıf/Citation: Aykal, F. D, Erbaş Özil, M. (2021). Biyofilik Tasarımın Diyarbakır Geleneksel Konutlarında Araştırılması. Journal of Architectural Sciences and Applications, 6 (1), 45-58. DOI: 10.30785/mbud.801022 


\section{Giriş}

Biyofili kavramı, "biyo" ve "fili" kelimelerinin birleşiminden oluşmaktadır. "Biyo" kelimesi "canlı" veya "yaşamak" anlamına gelmektedir, "fili" kelimesi "insanların doğal ortamlardaki bazı canlılara, eylemlere veya varlıklara karşı hissettikleri olumlu duygular" anlamına gelmektedir. Biyofili kavramı ilk defa 1964 yılında psikolog Erich Fromm tarafından kullanılmıştır. Erich Fromm bu kavramı, "Canlı ve yaşamsal olan şeylerin insanları etkilemesi; yaşayan her şeyin onları cezbedebildiği psikolojik saplantı" olarak kullanmıştır. (Fromm 1964; aktaran, Kayıhan, Güney ve Ünal 2018:2).

Biyofili kavramını ikinci kez kullanan kişi akademisyen ve entomolog Edward O. Wilson'dur. Edward O. Wilson 1980 'lerde bu terimi "yaşam ve gerçekçi süreçlere odaklanma, doğuştan gelen bir eğilim", "insanların diğer canlılara doğuştan gelen duygusal bağlantısı" olarak kullanmıştır. Wilson, "Biophilia" adlı kitabında, insanların doğaya ve biyolojilerine derin aşinalıklarının biyolojik üretimden kaynaklandığını ileri sürmektedir (Wilson, 1984).

Edward O. Wilson'un biyofili hipotezi üzerine görüşü, insanoğlunun biyomerkezli dünyadaki evrimini desteklemektedir. Wilson, insanın canlı organizmalara karşı duyduğu ilgi ve sevginin evrimin ilk dönemlerine kadar uzandığını vurgulamaktadır (Kara, 2004:5). Stephen Kellert biyofili hipotezini insanların doğayla ve doğadaki formların karmaşık geometrisiyle temas kurmalarına, metabolizmalarının besinlere ve havaya ihtiyaç duyduğu kadar bu temasa da ihtiyacı olduğu şeklinde açıklamıştır. Bu hipotez ayrıca; insanların neden ev hayvanları beslediklerini, bitki yetiştirdiklerini, hayvanat bahçelerini ziyaret ettiklerini, yeşille ve doğal yaşamla iç içe olmaktan hoşlandıklarını, bazen tehlikedeki bir canlıyı kurtarmak için kendi hayatlarını tehlikeye attıklarını da açıklamaktadır (Beyaz, 2017:4).

Biyofilik tasarım, mimari alanlar ve bir dizi doğuştan gelen insani özellikler arasındaki doğa temelli diyaloğa yol açan yenilikçi bir disiplindir. Fraktallardan oluşma ve ölçek değişmezliği gibi biyolojik formların geometrik özelliklerinin yanı sıra, simetri kavramları, öz benzeşlik ve kompleks hiyerarşinin de dolaylı olarak insanlarla doğal unsurların örüntüsü ve özellikleri arasında bağlantı kurduğu ileri sürülmektedir. Deneysel sonuçlar bu form ve niteliklerin, mimarların mevcut durumda sahip olduğundan daha özgün ve sağlıklı seçenekler sunarak fiziksel yapılara, belirlenebilen 'yaşama biçimleri' sağladığını ortaya çıkarmaktadır. Bu bağlamda, doğayı inşa edilmiş çevrenin içine dâhil etmek lüks değil aksine, sağlık ve üretkenlik anlamında iyi araştırılmıs nörolojik ve psikolojik kanıtlara dayanarak yapılan güvenilir ve ekonomik yöntemdir (Beyaz, 2017:4).

\subsection{Biyofilik Tasarım}

Kellert ve Wilson'a (1993) göre "Biyofili", modern dünyada insanların fiziksel ve zihinsel sağılı ve refahı için önemli olmaya devam eden ve insanın içinde var olan doğaya bağlı kalmanın bir eğilimidir. Biyofili fikri, geçmişten günümüze, doğal güçlere adaptasyon olarak biyolojik anlamda gelişen insan evrimi anlayışıyla bütünleşmektedir (Kellert ve Calabrese, 2015:3).

"Biyofili olgusunun, pozitif deneyimler yoluyla doğanın insan sağlığı, refahı ve iyiliğini destekleme misyonunun yapılı çevreye uygulanması yorumundan ortaya çıkan "biyofilik tasarım"; Sosyal Ekoloji Profesörü S. Kellert tarafından "RÇT" In bir boyutu olarak tanımlanarak literatüre kazandırılmıştır" (Ünlü, 2017: 59).

Biyofilik tasarımın temel amacı, insanın doğa ile kopuşundan sonra dünya ile arasındaki bu bağlantıyı yeniden kurmaktır. Yapılı çevre içinde bulunan doğanın olumlu deneyimini insan odaklı ortaya çıkarmayı ve korumayı vurgulamaktadır. Biyofilik tasarım, aynı zamanda doğanın psikolojik olarak fayda sağlayabileceği etkileri, yapılı çevreye dâhil etmeye odaklıdır. Bu anlamda mimaride doğa, yaşam ve mimarlık teorisini birleştiren yenilikçi bir yaklaşımdır (Ünlü 2017: 59). Ayrıca ampirik kanıtlar, biyofilik tasarımda odak noktası olan doğa, doğal oluşum ve tasarımların, insanlar üzerinde psikolojik olarak genel-iyi olma duygularını geliştirdiğini ve fizyolojik anlamda da olumlu etkilerinin olduğunu göstermektedir (Gündüz, 2019:49).

Kellert ve Calabrese'e (2015) göre biyofilik tasarımın uygulanması, deneyimler ve nitelikler olarak adlandırılan çeşitli tasarım stratejilerinin uygulanmasını içermektedir. Hangi tasarım uygulamalarının 
kullanılacağı projenin koşullarına, proje büyüklüğüne, değişen ekonomik, lojistik ve düzenleyici faktörlere bağlıdır. Bunun yanı sıra kültürel ve ekolojik koşullara bağlı olarak da değişmektedir. Burada en önemli koşul da biyofilik tasarımın asla parçalı veya bağlantısız şekilde değil, entegre bir ekolojik bütünle sonuçlanacak şekilde gerçekleşmesidir (Şekil 1).

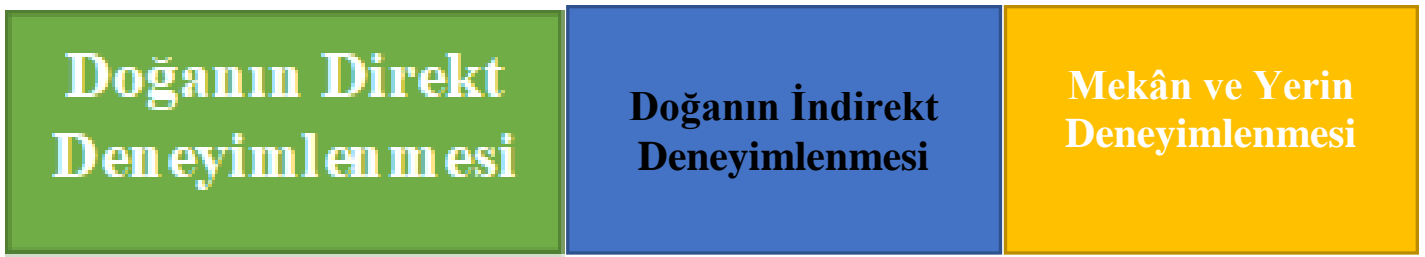

Şekil 1. Biyofilik tasarım deneyim ve nitelikleri (Kellert ve Calabrese, 2015:10)

\subsubsection{Biyofilik tasarımda doğanın doğrudan/direkt deneyimlenmesi}

Doğrudan doğa deneyimi, ışık, hava, su, bitkiler, hayvanlar, hava koşulları, doğal manzaralar, ekosistemler ve ateş gibi doğal unsurların bina tasarımında doğrudan kullanılması ilkesine dayanmaktadır (Kayıhan vd., 2018:4) (Çizelge 1).

Çizelge 1. Doğanın doğrudan deneyimlenme nitelikleri (Kellert ve Calabrese, 2015)

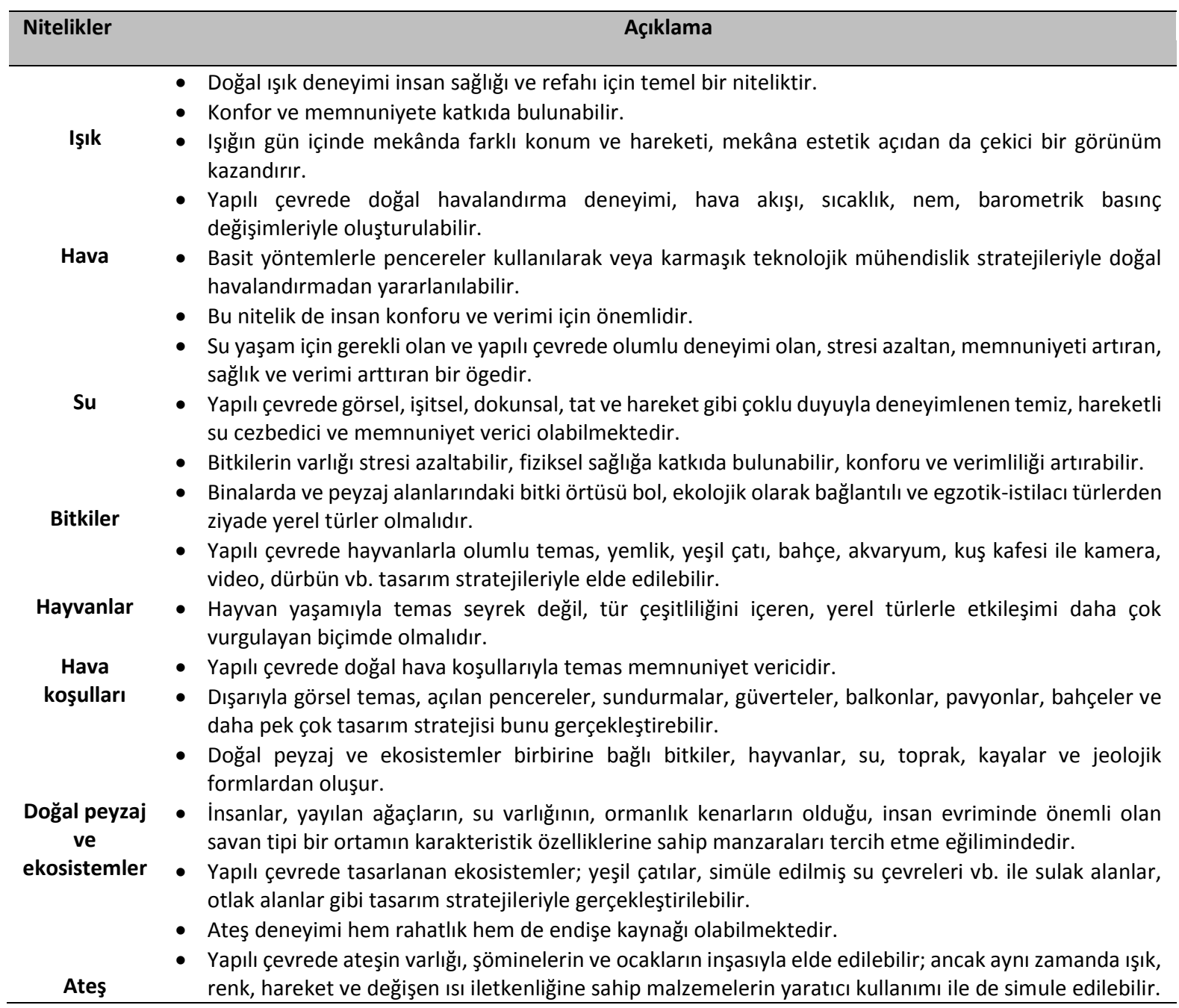

\subsubsection{Biyofilik tasarımda doğanın dolaylı/indirekt deneyimlenmesi}

Tasarımda doğanın dolaylı deneyimi, doğal unsurların direkt kullanımı yerine dolaylı yoldan bağlantı kurulması ile gerçekleşmektedir. Gerçek doğa yerine; doğal şekil ve formları simule eden dekoratif öğeler, şekli değiştirilmiş ağaç, taş gibi iç mekân mobilyaları, metaforik ögeler ya da resimler vb. ile peyzaj alanları ve organizmaların sembollerini içeren temsili gösterimlerle bağlantı kurmaktır (Kellert ve Calabrese, 2015:9) (Çizelge 2). 
Çizelge 2. Doğanın dolaylı yoldan deneyimlenme nitelikleri (Kellert ve Calabrese, 2015)

\begin{tabular}{lll}
\hline Nitelikler & \multicolumn{1}{c}{ Açıklama } \\
\hline & $\bullet \begin{array}{l}\text { Yapılı çevrede bitki, hayvan, manzara, su, jeolojik özellikler vb. hem duygusal hem de zihinsel } \\
\text { olarak tatmin edici olabilmektedir. }\end{array}$ \\
\hline Doğa imajları & $\begin{array}{l}\text { Bu görüntüler dolaylı yoldan, fotoğraf, resim, heykel, duvar resmi, video, bilgisayar } \\
\text { simülasyonu gibi araçlarla sağlanabilmektedir. }\end{array}$
\end{tabular}

- Doğal malzemeler, organik maddenin dinamik özelliklerini yansıttığından uyarıcı

Doğal Malzemeler olabilmektedir. Malzemelerin doğadan yapıya dönüşümü olumlu görsel ve dokunsal tepkileri uyarmaktadır.

\begin{tabular}{ccl}
\hline Doğal Renkler & $\bullet \begin{array}{l}\text { Biyofilik uygulamada rengin etkili kullanımı genellikle toprak, kaya ve bitkilerin karakteristik } \\
\text { soft "toprak" tonlarının desteklenmesidir. }\end{array}$ \\
& $\begin{array}{l}\text { Parlak renklerin kullanımı dikkatli bir şekilde uygulanmalı; çok yapay ve zıt renklerin bir arada } \\
\text { kullanımından kaçınılmalıdır. }\end{array}$ \\
\hline $\begin{array}{c}\text { Doğal ışı ve hava } \\
\text { simülasyonu }\end{array}$ & $\bullet \begin{array}{l}\text { Yapay ışık, doğal ışı̆ın spektral ve dinamik özelliklerini taklit edebilecek şekilde tasarlanabilir. } \\
\text { kalitesi taklit edilebilir. }\end{array}$
\end{tabular}

- Doğal dünyanın karakteristik şekil ve formları; sütunlarda bulunan yaprak benzeri desenleri,

Doğal biçimler ve formlar bina cephelerinde bitki motifleri, kumaşlara ve kaplamalara dokunan hayvan figürleri gibi birçok alanda çeşitlendirilebilir.

- Doğal şekil ve formların kullanımı, yapay çevreyi yaşayan bir sistemin dinamik ve ortam niteliklerine sahip olan bir alana dönüştürebilir.
Bilgi zenginliği

- Doğal ya da yapılı çevrede insanlar, tutarlı ve okunaklı yolla deneyimledikleri, seçenek ve fırsat çeşitliliği olan, bilgi yönüyle zengin çevrelere olumlu tepki verme eğilimindedir.

\footnotetext{
Yaş, Değişim ve

Zamanın Patinası

- Doğa sürekli değişip akarken, yaşamın, büyüme ve yaşlanmanın dinamik güçlerini yansıtmaktadır.

- Değişen koşullara adaptif cevap, doğanın kapasitesini ortaya koyduğundan insanlar bu dinamik güçlere ve zamanın patinasına olumlu yanıt vermektedir.
}

\footnotetext{
Doğal Geometriler • Doğal geometriler, doğada yaygın olarak karşılaşılan matematiksel özellikleri ifade etmektedir.

- Diğer önemli doğal geometriler arasında "Altın Oran" ve "Fibonacci Dizisi" gibi hiyerarşik olarak düzenlenmiş ölçekler bulunmaktadır.

Biyomimikri

- İnsanlar dışında doğada bulunan diğer türlerin form ve işlevlerinin kullanılmasıdır. Bu aynı zamanda insanların doğal dünyayla ilgili hayranlık duymalarına da sağlamaktadır.
}

Insan sağlığı ve refahını geliştiren doğal çevrenin karakteristik mekânsal özelliklerini ayrıca; mekân duygusunu, mekânın doğal bağlantılarını ve çağrışımlarını ifade etmektedir. Bu deneyimin nitelikleri insanlarda alışkın olduğu doğal ortamları hatırlatır (Kayıhan ve diğerleri, 2018:4; Kellert ve Calabrese, 2015:9) (Çizelge 3). 
Çizelge 3. Doğanın dolaylı yoldan deneyimlenme nitelikleri (Kellert ve Calabrese, 2015)

\begin{tabular}{|c|c|}
\hline Nitelikler & Açıklama \\
\hline $\begin{array}{l}\text { Manzara ve korunaklı } \\
\text { alan }\end{array}$ & $\begin{array}{l}\text { - Manzara, insanların uzak mesafedeki güzel görünümleri ve tehlikeli algılamasına } \\
\text { olanak verirken; korunaklı alan, insanlara güvenli ve emniyetli alanlar sunar. } \\
\text { - Bu nitelik yapılı çevrede hem işlevsel hem de tatmin edicidir. } \\
\text { - Bu biyofılik hedef, dış manzarayla iç mekânlar arasında görsel bağlantılar } \\
\text { kurulması, güvenli ve korunaklı mekânlar oluşturulması gibi tasarım stratejileri ile } \\
\text { sağlanabilir. }\end{array}$ \\
\hline Organize karmaşıklık & $\begin{array}{l}\text { - Insanlar, seçenekler ve fırsatlar açısından zengin olan doğal ortamlarda karmaşıklığı } \\
\text { göze alabilmektedir. } \\
\text { - En tatmin edici çevreler, düzenli ve organize karmaşıklık niteliklerine sahip } \\
\text { olanlardır. Karmaşık mekânlar değişkenlik ve çeşitlilik gösterirken, organize alanlar } \\
\text { uzlaşım ve tutarlıık gösterir. }\end{array}$ \\
\hline $\begin{array}{c}\text { Parçaların bütünle } \\
\text { entegrasyonu }\end{array}$ & $\begin{array}{l}\text { - Insanlar için, farklı parçaların entegre bir bütünü içerdiği ortamlar tatmin edicidir. } \\
\text { - Bu bütünlük hissi hem mekânların ardışık bağlantısı ile hem de sınırların fark } \\
\text { edilebilir birleşimiyle elde edilebilir. }\end{array}$ \\
\hline Geçiş mekânları & $\begin{array}{l}\text { - Bir çevrede başarılı şekilde gezinmek, genellikle anlaşılır geçiş ve bağlantılara } \\
\text { bağlıdır. } \\
\text { - Bu alanlar koridorlar, eşikler, kapılar, sundurmalar ve avlular vb. gibi geçiş } \\
\text { alanlarıdır. }\end{array}$ \\
\hline $\begin{array}{l}\text { Hareketlilik ve yön } \\
\text { bulma }\end{array}$ & $\begin{array}{l}\text { - Insanların konforu ve refahı genellikle karmaşık alanlar arasında özgürce hareket } \\
\text { etmeye dayanmaktadır. } \\
\text { - Kolay anlaşılabilen yollar ve giriş-çıkış noktaları rahat hareket edebilme ve güvenlik } \\
\text { duygularını tetiklerken, bu özelliklerin yokluğu da karışıklık ve kaygı yaratmaktadır. }\end{array}$ \\
\hline $\begin{array}{l}\text { Yerel kültürel ve } \\
\text { ekolojik bağlılık }\end{array}$ & $\begin{array}{l}\text { - Tanıdık yerlere yakınlık, kültürel ve ekolojik yöntemlerle oluşturulabilen bölgesel } \\
\text { eğilimi yansıtmaktadır. } \\
\text { - Yere kültürel ve ekolojik bağlantılar insanları, bir bölgeye duygusal bağlanmaya; } \\
\text { yerel peyzaj, yerli bitki örtüsü, faunası ve karakteristik meteorolojik koşulların } \\
\text { farkındalığına; doğal ve yapay çevreleri koruma ve sürdürmeye teşvik eder. }\end{array}$ \\
\hline
\end{tabular}

\subsection{Diyarbakır Geleneksel Evleri}

Diyarbakır tarihi evleri, geleneksel Türk evlerinde olduğu gibi değişik birimlerden oluşmaktadır. Kentin surlarla çevrili oluşu, yerleşim birimlerinin de bu alanda gelişmesine neden olmuştur. Sıcak iklimin etkisi ile bitişik avlulu yapılar oluşmuştur. Bu oluşum organik bir sokak dokusuna neden olmuştur. Mahremiyet nedeniyle parsellerin sokak cephelerinde yüksek duvarlar kullanılmıştır. Böylece dışarıdan evin içi görülmemektedir. Yine yan parsellerde yapılan evlerin kat yüksekliğine dikkat edilmiş ve komşu parsellere bakan duvarlarda pencereler açılmamıştır.

Diyarbakır tarihi evlerinde avlu evin merkezi konumundadır. Mekânlar arasındaki bağlantı avlu ile sağlanmaktadır (Şekil 2).
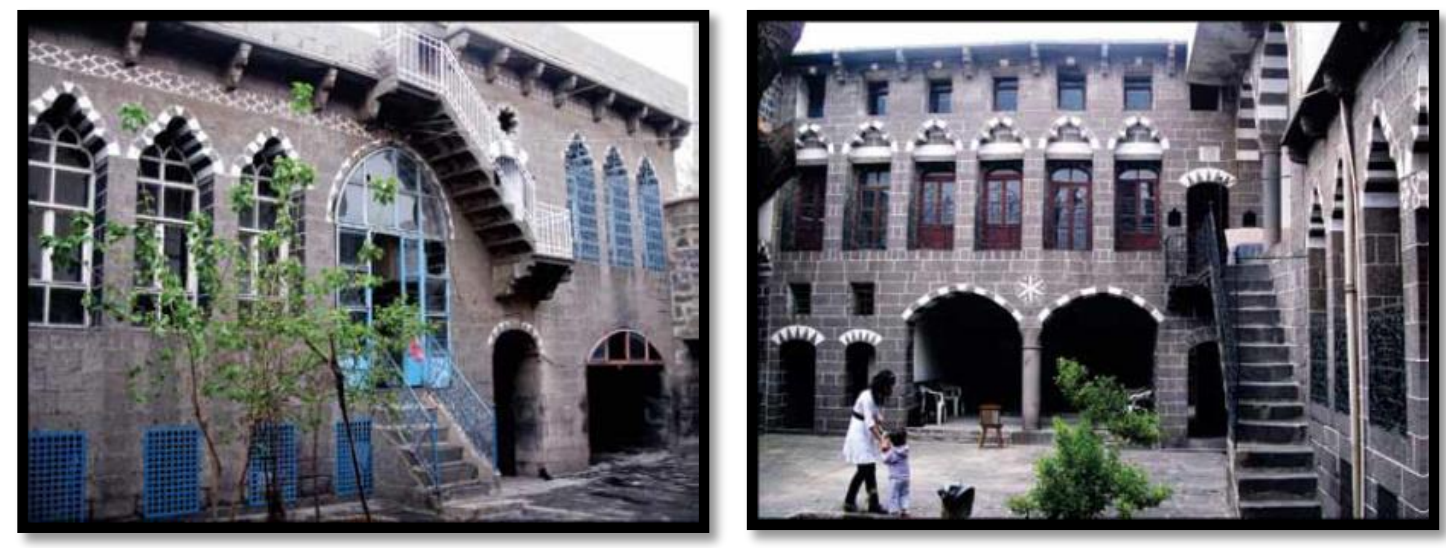

Şekil 2. Diyarbakır geleneksel evi avlu örnekleri

Evlerin planları dikdörtgen, kare ya da yamuk planlı avlu ve etrafında yer alan bir, iki ve üç katlı kanatlardan oluşmaktadır. Plan formunu oluşturan birimler, yaşama ve servis birimleri olarak 
gruplandırılmaktadır. Avlu, eyvan, soğukluk, sofa ve odalar yaşam birimlerini; mutfak, banyo, tuvalet, kiler ve depo ise servis birimlerini oluşturmaktadır (Şekil 3).
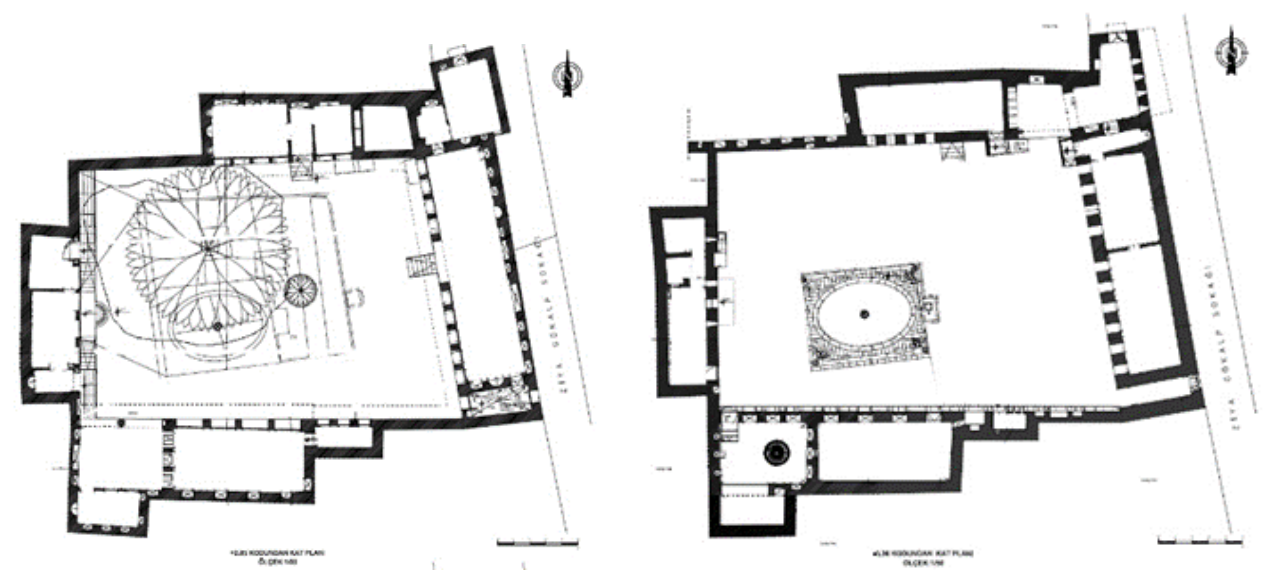

Şekil 3. Diyarbakır geleneksel evinden plan örneği (Yıldırım ve diğerleri, 2012)

Yapının zemin katında, mutfak, tuvalet, ahır ve varsa banyo gibi servis birimleri ile eyvanlar ve odalar bulunmaktadır. Bodrum kat her evde olup, depo ya da kiler amaçı kullanılmıştır. Zemin ile üst kat arasındaki bağlantı, avlu, eyvan veya sofadaki merdivenlerle; bodrum katla bağlantı ise avludaki basamaklarla sağlanmıştır.

Avlular, bahar ve yaz aylarında, gündüzleri oturma, bulaşık, çamaşır yıkama, yemek hazırlama; geceleri uyuma gibi eylemlerin yapıldığı bir birimdir. Eyvanlar, üç tarafı kapalı, sadece avluya bakan cephesi açık bir yaz odası konumundadır. Günlük yaşamın büyük bir bölümü burada geçmektedir. Serin olabilmesi için genellikle evin güney kanadında bulunup, kuzeye yönlendirilmiştir (Şekil 4). 

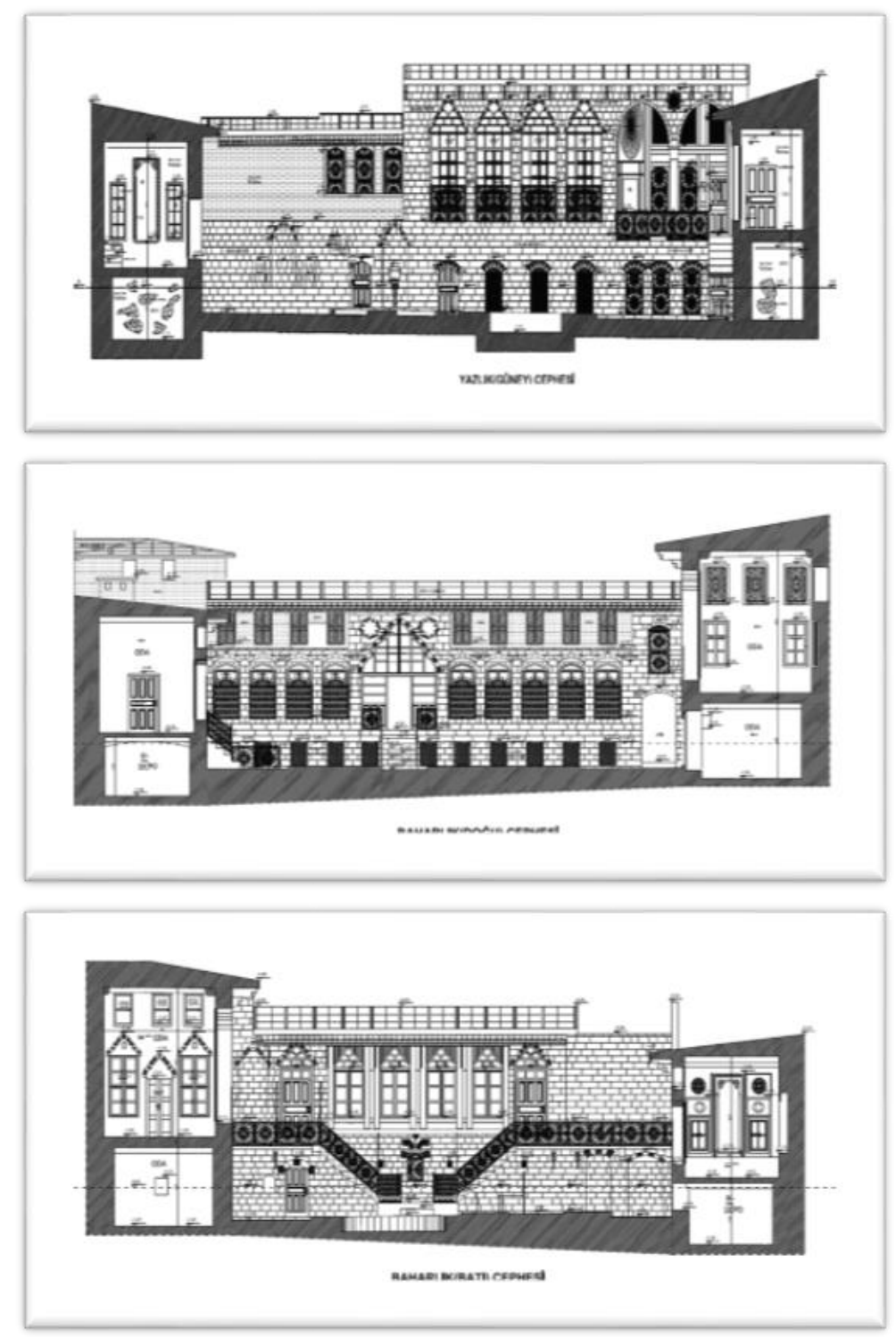

Şekil 4. Diyarbakır geleneksel evinden kesit ve görünüş örneği (Yıldırım vd., 2012)

Büyük evlerin bazılarında soğukluk bulunmaktadır (Şekil 5).
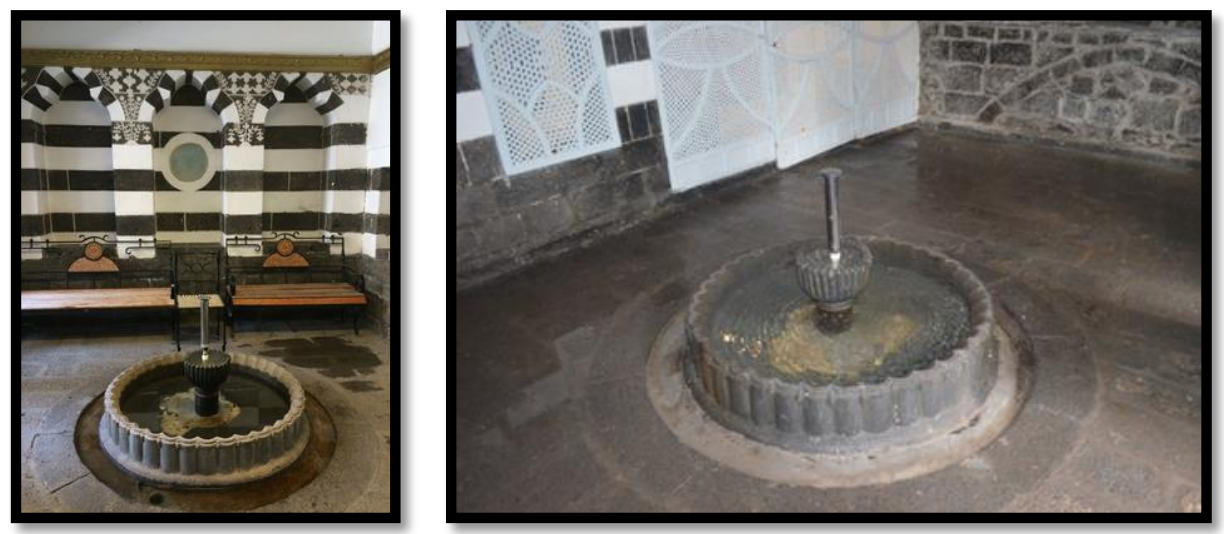

Şekil 5. Diyarbakır geleneksel evi serdap örneği

Bu nedenle bodrum katında veya avlu kotundan birkaç basamak aşağıda yer almaktadır. Soğukluk, yazın sıcak günlerinde kullanılan kapalı bir mekândır. Ortasında küçük bir havuz bulunmaktadır. 
Sofalar, zemin katta avluyla bağlantılı olan, odalar arası ve katlar arası bağlantıyı sağlayan kapalı bir mekândır. İki yanında ya da üç tarafında odalar bulunmaktadır. Bazen iki kat arasındaki bağlantı buralardaki merdivenlerle sağlanmaktadır (Şekil 6).
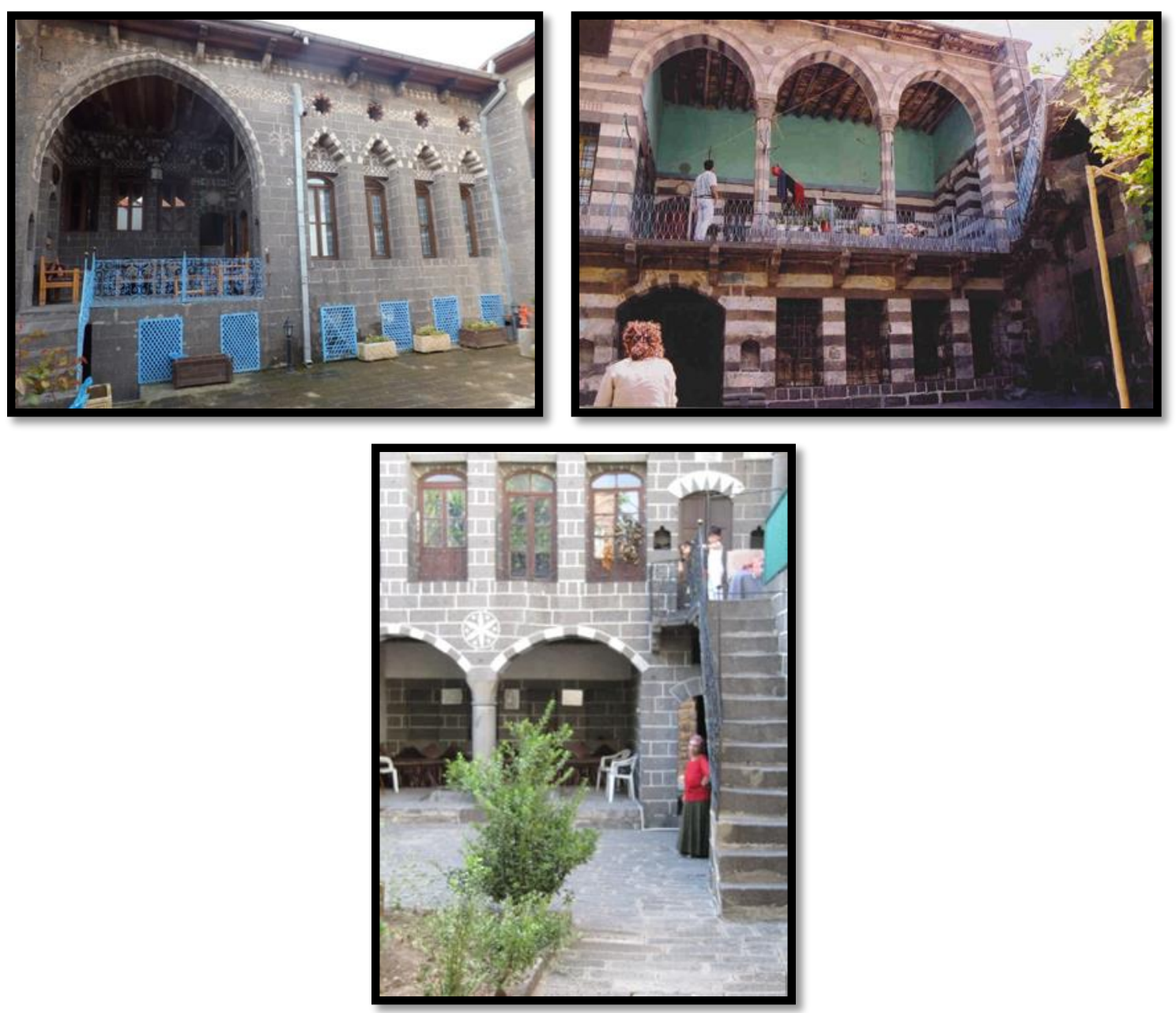

Şekil 6. Diyarbakır geleneksel evi avlu sofa ilişkisi

Mutfak genellikle kuzey kanatta yer almaktadır. Avluya açılan tek kemerli bir eyvan görünümündedir. Içinde bir ocak ve ona bağlı bir baca bulunmaktadır (Şekil 7). Su tesisatı yoktur.

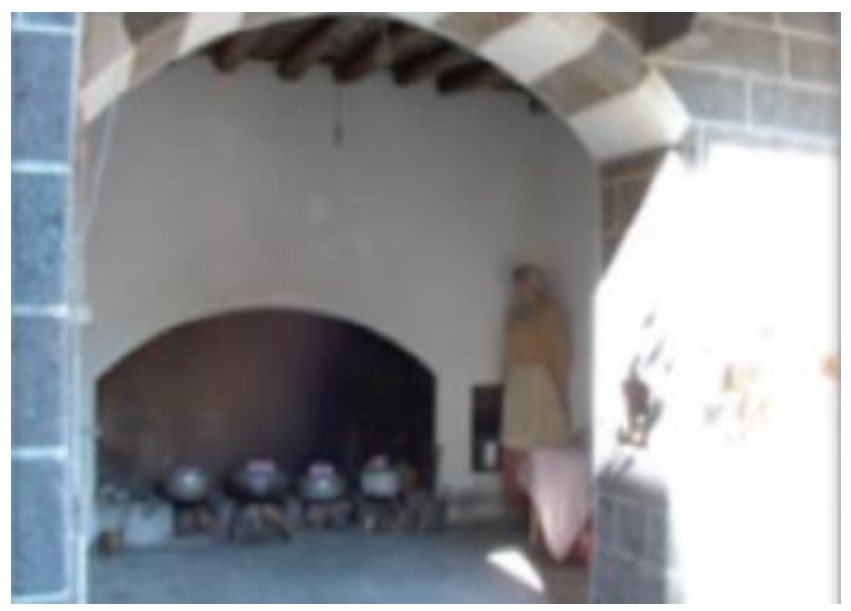

Şekil 7. Diyarbakır geleneksel evinin mutfakta ocak örneği

Tuvaletler zemin katta, sokağa yakın avlu duvarının bir kenarında, merdiven altında; birinci katta ise genellikle merdiven başlarında, sokağa çıkma yapacak şekildedir. Tuvaletler, sokaklardaki kanalizasyon sistemine en kısa yoldan ulaşmak için, sokağa yakın yapılmışlardır. 
Evlerin dış cephe mimarisi oldukça sade olup, avlu cepheleri zengin mimari özellikler gösterir. Avlu cephelerinde beyaz derzler, yüksek kemerli eyvanlar ve farklı kemer türleri kullanılmıştır.

\section{Materyal ve Yöntem}

Biyofilik tasarım, mimari alanlar ve bir dizi doğuştan gelen insani özellikler arasındaki doğa temelli diyaloğa yol açan yenilikçi bir disiplin olarak bilinmektedir. Bu diyaloğu kurmak için gereken belirli stratejiler; günışığı, temiz hava, bitkiler ve yeşil alanlara doğrudan erişimi içermekte fakat bununla sınırı kalmamaktadır. Ancak bu disiplinin geçmiş dönemlerde de insanoğlu tarafından kullanıldığı varsayılmaktadır. Bu varsayımla araştırma Diyarbakır geleneksel evleri üzerinde geliştirilmiştir. Bu bağlamda seçilen evler biyofilik tasarım stratejilerinin uygulanması açısından temel teşkil eden deneyimler ve özellikler doğrultusunda ele alınmıştır. Yapılarda, iklimsel verilere bağlı olarak, farklı yönlerde mekânlar tasarlanmış, bu mekânlar mevsimlere göre kullanılmıştır. Böylece farklı tipolojik tasarımlar ortaya çıkmıştır.

Çalışmada, biyofilik tasarımın günümüzde faydalı olması için uygulanabilir biyofilik unsurların nasıl kullanıldığının literatür üzerinden tespiti yapılarak, doğanın mantığını ve yaşamın dilini inşa edilmiş çevreye dâhil etmek için gereken kriterler, stratejiler ve düzenlemelerin bir çerçeve dâhilinde sunulması hedeflenmiştir. Konunun daha somut olarak anlaşılmasının sağlanarak, ülkemiz mimarlığı için bir perspektif oluşturulması ve konut yapıları tasarımına ışık tutulması amaçlanmaktadır.

Bu kapsamda öncelikle kavramsal altyapıya yönelik literatür taraması yapılarak insan ve doğa arasındaki ilişki ve biyofilik tasarım kavramı ile ilgili kaynaklar taranmış, The Practice of Biophilic Design (Kellert ve Calabrese, 2015)'da yer alan biyofilik tasarım stratejilerinin uygulanması açısından temel teşkil eden deneyimler ve özellikler açıklanmıştır.

Yapılar, gözlem metoduyla incelenmiştir. Kellert (2015)'in biyofilik tasarım eleman ve niteliklerinin kullanıldığı değerlendirme tablosunda, seçilen konut yapılarında biyofilik niteliklerin varlığı tespit edilerek ilgili çizim ve fotoğraflarla desteklenmiştir. Bu sayede örnek konut yapılarında biyofilik tasarım unsurlarının varlığı/yokluğu ve nelerin kullanıldığı belirlenmeye çalışımıştır.

\section{Araştırma Bulguları}

Geleneksel Diyarbakır evlerinde ışık, yönünün önemli bir paydası olarak kullanılmıştır. İlimsel verilere bağlı olarak ışık, yönlere göre pencereler ya da tepe pencereleri ile yapı içine alınmış, doğal aydınlatma sağlanmıştır. Pencereler aynı zamanda yapı içine doğal havanın girebilmesi ve hava sirkülasyonu ile doğal iklimlendirmenin gerçekleştirilmesinde önemli olmuştur. Kullanılan avlu ise yine hava sirkülasyonu, sıcak dönemlerde serinleme ve serinletme amaçlı kullanılmıştır

Biyofilik tasarımda doğanın doğrudan deneyimlenmesi, Diyarbakır Geleneksel Evleri'nde tasarımda etkili olan önemli bir yaklaşımdır. Evlerin avlusunda bulunan havuzlar suyun sesi ve serinliği ile yapılara ayrı bir konfor sağlamışır. Kimi zaman havuzlar, serdap adı verilen odalarda kullanılarak yazın serin ortamlar sağlanmıştır. Yine su öğesi havuz bulunmayan evlerde, tulumbalarla yapıya kazandırımıştır. Tulumbadan çekilen sular ile yıkanan avlu, serin bir ortam yaratarak iklimsel konfora katkı sunmuştur. Nadir sayıdaki evde ise çeşme kullanımına rastlanmaktadır. Havuzlar etrafında yetiştirilen bitkiler, ayrıca Diyarbakır'da önemli olan ipek böcekçiliği için yetiştirilen dut ağaçları ile bitkiler de yapı alanı içinde, kullanııının doğa ile iç içe olmasını sağlamıştır. Aynı zamanda ipek böceği yetiştiriciliği ile insan hayvan ilişkisi sağlanmıştır. Havuzların kenarlarına yerleştirilen su kadehleri ile kuşların avluda insanlarla iç içe olması sağlanmıştır. Kimi evlerde güvercinler için evlerin damları kullanılııştır. Güvercinlerden elde edilen gübre ise Diyarbakır karpuzunun yetiştirilmesinde kullanılmıştır. Hava koşullarına bağlı olarak evlerin tipolojisi ortaya çıkmıştır. Böylelikle evler yazlık, kışlık ve mevsimlik bölümler olarak kullanılmıştır. Avlular doğal ekosistemi yaşatmak için, dişi bazalt taşı adı verilen, gözenekli yöresel taşlarla döşenmiştir. Havuzdan ya da tulumbadan alınan sular, taşların gözeneklerine dolarak yaz aylarında serin ortamların oluşmasını sağlamıştır. Biyofilik yaklaşımda kullanılan ateş, Diyarbakır Geleneksel Evleri'ndeki mutfak biriminde görülmektedir. Kimi büyük evlerin başodasında, vitray kullanımıyla ışık ve renk hareketiyle ateş faktörü simüle edilmiştir. Dolayısıyla Diyarbakır Geleneksel Evleri'nde biyofilik tasarımda doğanın doğrudan deneyimlenmesine ait parametrelerin tamamının kullanıldığı görülmektedir (Çizelge 4). 
Çizelge 4. Doğanın direkt deneyimlenmesi örnekleri

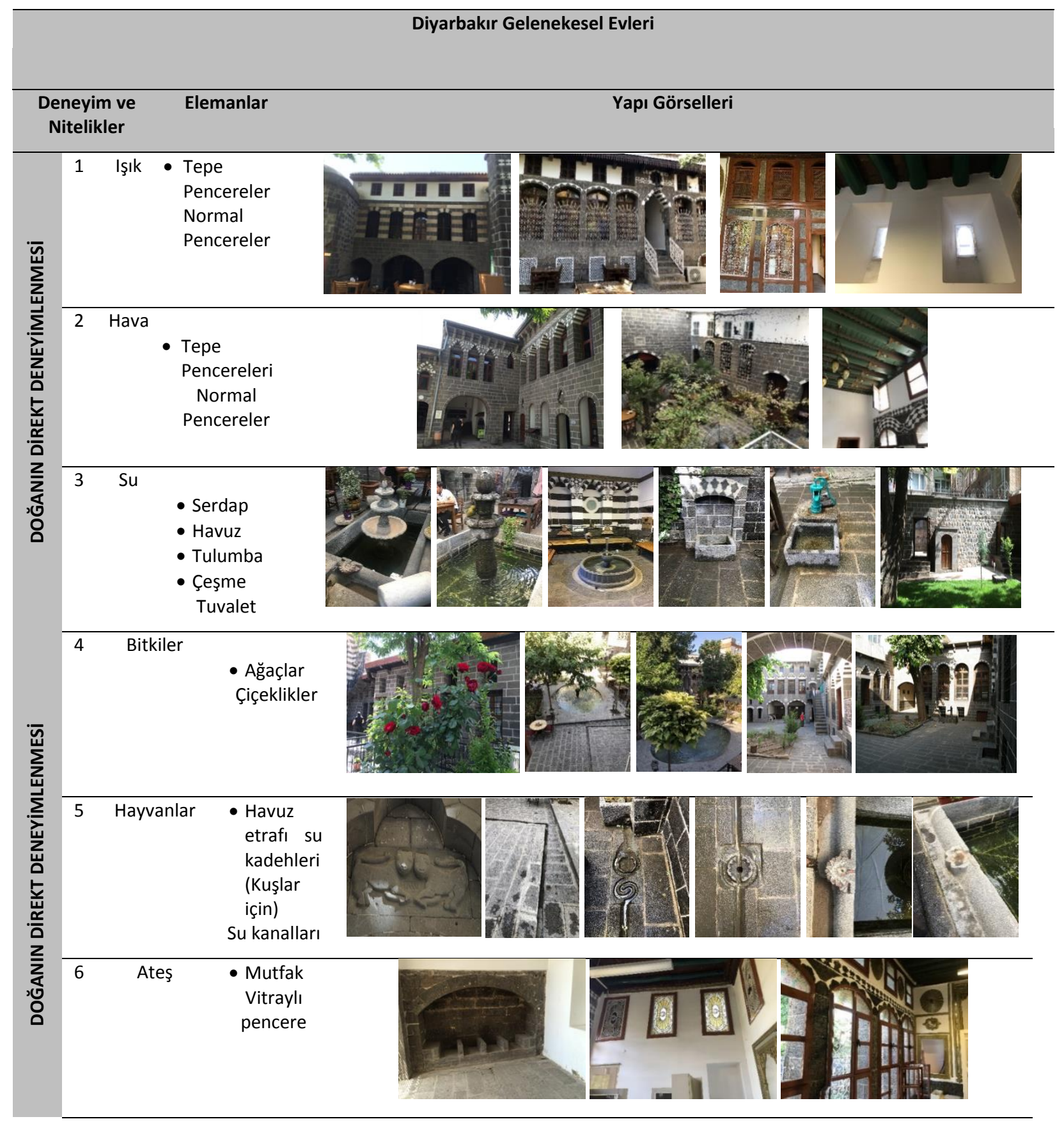

Biyofilik tasarımda doğanın indirekt deneyimlenmesi de Diyarbakır Geleneksel Evleri'nde kullanılmıştır. Diyarbakır Geleneksel Evleri'nde kullanılan bazalt taşı olup, yöresel doğal bir malzemedir. Yapısındaki gözeneklerin sıklığına bağlı olarak dişi bazalt ve erkek bazalt taş olarak farklı şekillerde kullanılmıştır. Aynı zamanda görsel etkisinde doku özelliğinin de kullanıcı tarafından hissedilmesi sağlanmıştır. Bazaltın koyu renginin hafifletilmesi için tamamen kontrast olan beyaz renk ile doğa resimleri; laleler, yapraklar özellikle avluya bakan cephelere resmedilerek bazaltın ağırlığı yine doğal görüntülerle hafifletilmiştir. Ayrıca kullanılan bazı geometrik formlar da renk, doğa, doğal formların yapıda kullanıldığı örnekler arasındadır. Hatta havuz kenarlarında kullanılmış olan su kadehlerindeki çiçek formu, avlularda suyun dolaşımını sağlayan spiral su kanalları, sütunların başlıklarında bulunan yaprak formları da doğayı çağrıştırmak için kullanıımış öğeler arasındadır (Çizelge 4). 
Çizelge 5. Doğanın indirekt deneyimlemesi örnekleri

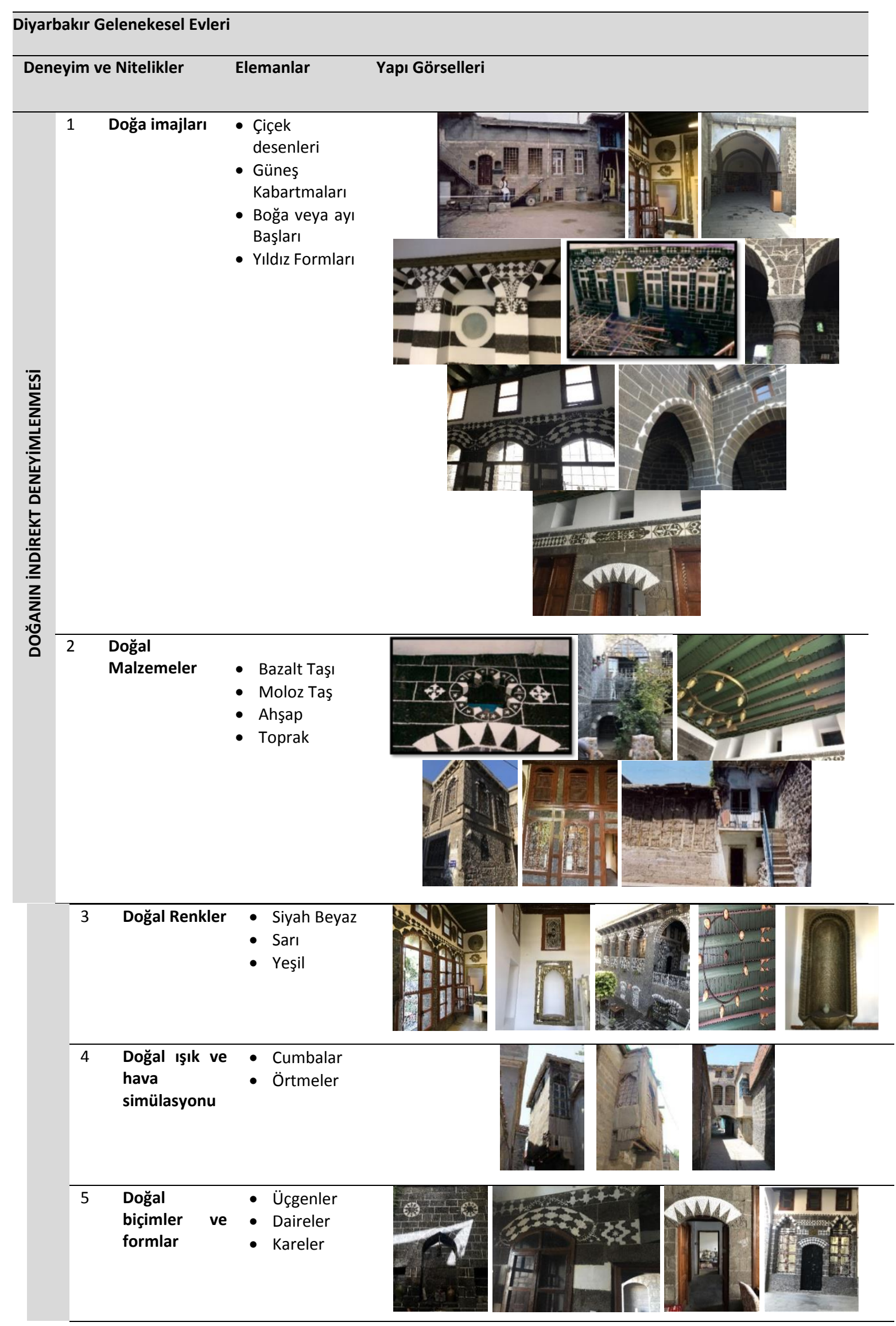




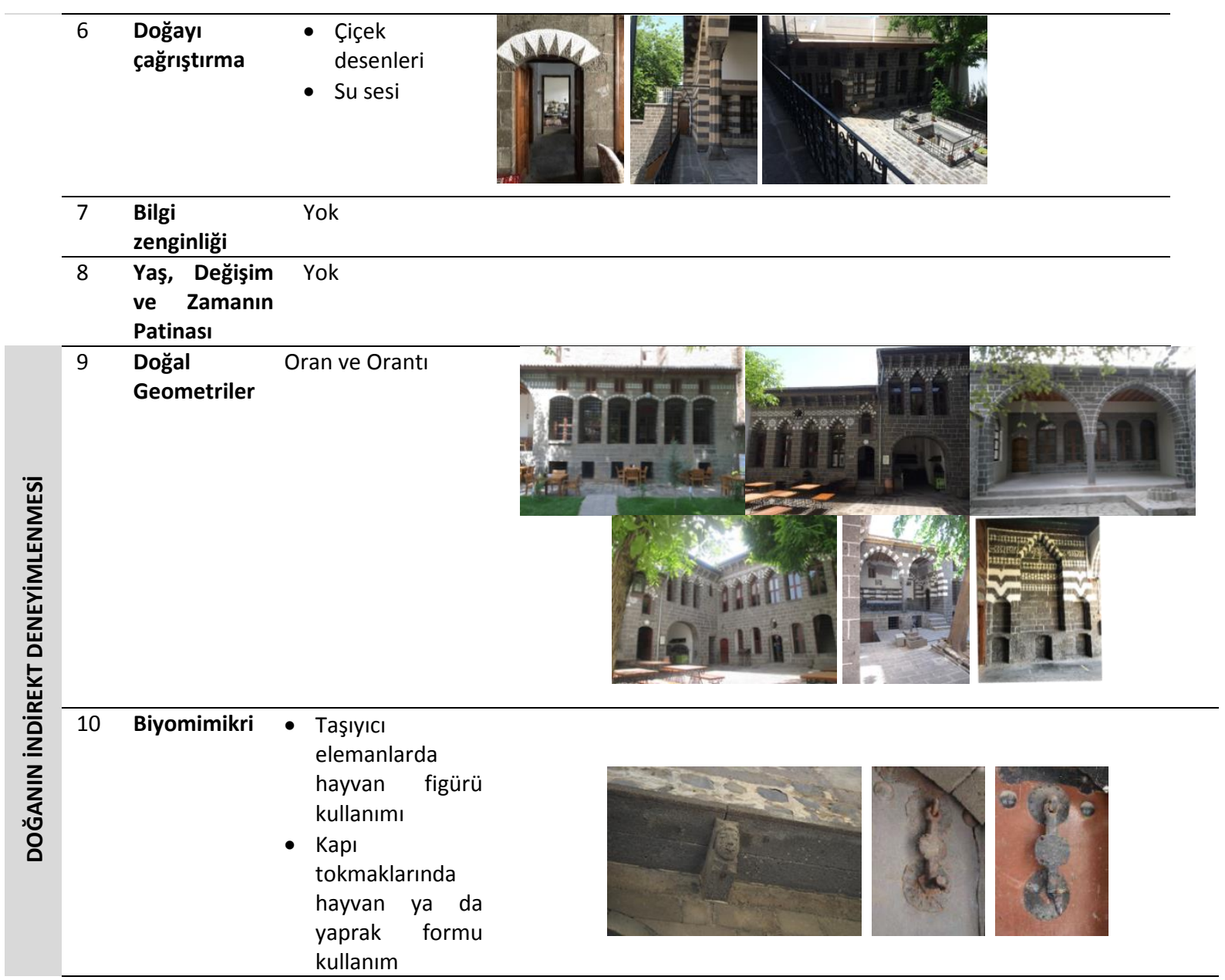

Biyofilik tasarımda mekân ve yerin deneyimlenmesinin, örnekleri de Diyarbakır geleneksel evleri'nde görülmektedir. Biyofilik tasarımda dış manzara ile iç mekânlar arasında görsel bağlantı kurulması önemli bir yaklaşımdır. Diyarbakır geleneksel evleri dışa kapalı avlu yönelimli yapılar olduğu için, avlu içinde su ve bitkilerle manzaralar yaratılmıs ve odaların, eyvanların, sofaların bu alanı görebilmesi sağlanmıştır.

Evlerdeki mekân kurgusu oldukça organize olup dengeli bir dağılım göstermektedir. Evlerde birinci derecedeki geçiş mekânı sokak arası olarak tanımlanan avlu ile sokağı bağlayan mekândır. Daha sonra odalara geçişi sağlayan avlu gelmektedir. Avlu ikinci derecede önemli olan geçiş mekânıdır. Tüm birimler avlu etrafında düzenlenmiştir. Avluya girildiği zaman, hangi mekânlara geçilebileceği ve mekânların taşıdığı fonksiyonlar kolaylıkla algılanabilmektedir. Bu durum aynı zamanda mekânların sınırlarının da algılanmasını da sağlamaktadır.

Yine odaları birbirine bağlayan sofalar ve üst katlarda odaların önünde yer alan balkon nitelikli gezemekler ve eyvanlar da geçiş mekânları olarak kullanılmıştır. Geleneksel Diyarbakır evlerinde böylelikle yapay bir çevrede doğal öğeler sürdürülmüş, kullanıcı konforu biyofilik yaklaşımla sağlanmıştır (Çizelge 6). 
Çizelge 6. Mekân ve yerin deneyimlenmesi örnekleri

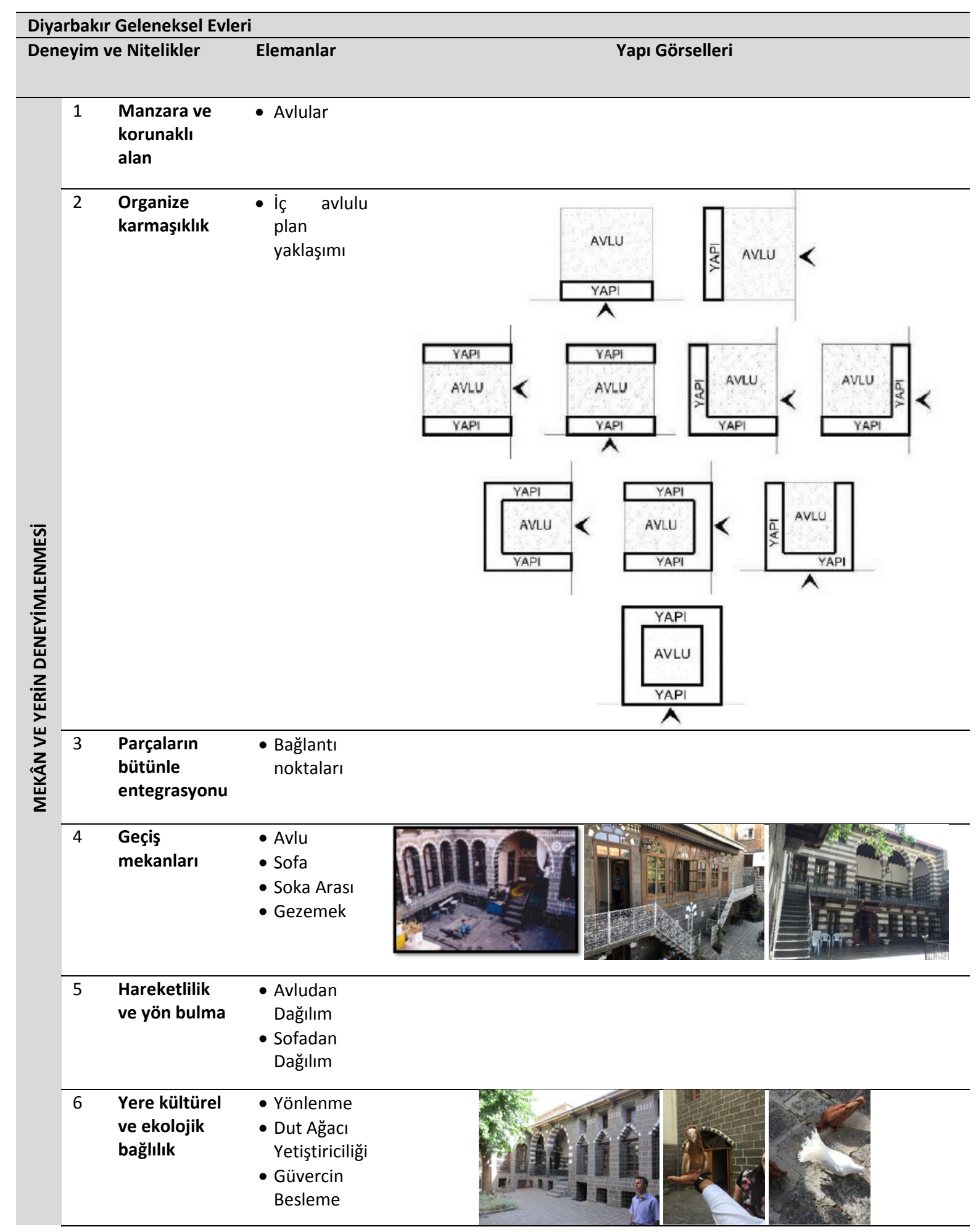

\section{Sonuç ve Öneriler}

Biyofilik tasarım temel olarak, "insanın yaşadığı yapılı çevreye doğal unsurların getirilmesi ve insandoğa ilişkisinin sürdürülmesi” olarak tanımlanmaktadır. Edward O. Wilson, insanın doğaya olan ihtiyacını, doğaya duyduğu içten gelen yakınlığını fark etmiş ve bunun farkındalığını sağlamak amacıyla biyofili hipotezi adı altında birçok akademik çalışma yapmıştır. Böylelikle biyofili terimini akademik literatüre katmıştır. Wilson ile çalışan Stephen Kellert ise bu konunun mimarlık ve tasarım bilim dalı için önemini ön görerek mimar olmamasına rağmen konunun uzmanları ile çalışarak biyofilik tasarım terimini mimarlık literatürüne kazandırmıştır. 
Yaklaşık 100- 150 yıllık bir geçmişe sahip olan Diyarbakır Geleneksel Evleri, teknolojik gelişmelerin çok gerisinde inşa edilmiş olmasına rağmen kullanıcılarının deneyimleriyle şekillenmiş yapı örnekleridir. Özellikle iklime göre yönlenme ve malzeme seçimi biyofilik yaklaşımın temel özelliklerinin göstergesidir. Kimi zaman uyum, kimi zaman kontrastın görüldüğü yapılarda gün ışığının en etkili kullanımı, manzara öğesinin yapı içinde yaratılması önemli özellikler arasındadır. Yapılan incelemeler sonucunda, doğanın direkt ve indirekt deneyimlenmesi ile mekân ve yer olduğu evlerde yoğun bir şekilde görülmektedir.

Mimarlık disiplininde tarihi yapılarda biyofilik yaklaşımlarla ilgili kayda değer sayıda çalışma bulunmamaktadır. Aslında tarihi yapılarda biyofilik tasarım yaklaşımlarının neler olduğunun tespit edilmesi günümüz tasarımcılarına bir ilham kaynağı olması açısından önem arz etmektedir. Bu nedenle çalışmada Diyarbakır geleneksel evleri örneği ile konunun önemine dikkat çekilmiştir.

\section{Teşekkür ve Bilgi Notu}

Makalede, ulusal ve uluslararası araştırma ve yayın etiğine uyulmuştur. Çalışmada etik kurul izni gerekmemiştir.

\section{Kaynaklar}

Beyaz, E. (2017). Beyşehir'deki XIII. ve XIV. Yüzyıl Camilerinin Biyofilik Kriterler Üzerinden İncelenmesi. KTO Karatay Üniversitesi Fen Bilimleri Enstitüsü Mimarlık Ana Bilim Dalı, Yüksek Lisans Tezi, Konya.

Fromm, E. O. (1964). The Heart of Man. UK: Harpercollins.

Gündüz, E. (2019). Mimaride Doğayı Temel Alan Tasarım Yaklaşımları İzleği. İstanbul Teknik Üniversitesi Fen Bilimleri Enstitüsü Mimarlık Anabilim Dalı, Yüksek Lisans Tezi, İstanbul.

Kara, D. (2004). Bir Biyofilik Olarak Joseph Beuys ve Sanatı. Marmara Üniversitesi Güzel Sanatlar Enstitüsü Resim Ana sanat Dalı, Yüksek Lisans Tezi, İstanbul.

Kayıhan, K. (2018). Examination of Biophilia Phenomenon in the Context of Sustainable Architecture. Erişim adresi (10.02.2019): https://www.researchgate.net/publication/324063335.

Kayıhan, K., Güney S. ve Ünal F. (2018). Biophilia as the Main Design Question in Architectural Design Studio Teaching. Megaron, 13(1):1-12.

Kellert, S. ve Calabrese, E. (2015). The Practice of Biophilic Design. Erişim adresi (12.02.2019): www.biophilic-design.com

Kellert, S. and Wilson, E. O. (1993). The Biophilia Hypothesis, Island Press, Washington, DC. 484 pages. ISBN: 1-55963-148-1.

Ünlü, E. (2017). Mimarlıkta Biyofili Olgusu ve Sağlık Yapıları Örneği. Gebze Teknik Üniversitesi Fen Bilimleri Enstitüsü Mimarlık Anabilim Dalı, Yüksek Lisans Tezi, Gebze.

Wilson, E. (1984). Biophilia, ABD. Erişim Adresi (14.03.2019): https://epdf.pub/biophilia.html

Yıldııım, M., Dalkılıç, N., Halifeoğlu, F. M., Dağtekin, E. ve Payaslı Oğuz, G. (2012). D. Ü. Mimarlık Fak. Rölöve Teknikleri Dersi Öğrenci Çalışmaları, TMMOB Diyarbakır Şubesi Yayınları, 1. Baskı. 